Arab Univ. J. Agric. Sci., Ain Shams Univ., Cairo, 13(3), 707-715, 2005

\title{
EFFECT OF THE NATURE OF THE FEEDING RESOURCE ON ITS IN VITRO GAS PRODUCTION KINETICS USING RUMEN FLUID OF SLAUGHTERED DROMEDARY
}

[46]

\author{
Arhab, R'; A. Dehimi²; Y. Dib² and H. Bousseboua ${ }^{1, a}$
}

\begin{abstract}
Degradation aspects in terms of kinetics of the tested samples namely dates, oranges and olive residues by the dromedary ruminal microflora is comparatively studied with vetch-oat hay as a standard. The results indicate greater hydrolytic activity of the dromedary ruminal microflora towards dates and orange residues than both olive residues and hay. Fermentation of dates and orange residues reaches their stationary phase after 24 hours and olive wastes after 48 hours. However, fermentation process was marked by two phase; namely the degradation of soluble fraction and that of cellulosic one. The results showed also that types of substrate is a determining factor for in vitro gas production. In fact, substrate rich in cellular content (dates and orange residues) is characterised by a fast fermentation that moves towards $\mathrm{CO}_{2}$ production, and it is marked by a long latency phase. On contrary, the fibrous substrate degradation (olive residues and hay) is tributary of less long latency period and generates $\mathrm{CH}_{4}$. The degradation level observed indicates that the dates and oranges residues might represent an acceptable source of energy for dromedary. On the other hand, the olive residues, in spite of being rich in organic matter, cannot be used in animal feeding.
\end{abstract}

Key words: Dromedary, Ruminal microflora, Agro-industrial by-products, In vitro gas production, $\mathrm{CO}_{2}$ and $\mathrm{CH}_{4}$.

\section{INTRODUCTION}

The lignocellulosic biomass that are composed of residues of harvest and agro-industrial by-products, represent considerable volume. It remains unexploited or degraded very slowly because it is generally considered as weakly degradable and therefore being without a real commercial value. However, such biomass provides a potential source to ruminant feeding

1- Laboratoire de Génie Microbiologique et Applications, Département des Sciences de la Nature et de la Vie, Faculté des Sciences, Université des Frères Mentouri, Route de Ain-El-Bey BP 325, 25017 Constantine (Algerie).

2- Institut Technique des Elevages/Ain Mlila, 04000 Oum EL Bouaghi (Algerie).

a. Correspondant: Pr. Bousseboua Hacène (Tél./Fax: 0021331641435.

E-mail: hblgma@yahoo.fr

(Received April 6, 2005)

(Accepted June 25, 2005) 
Arab Univ. J. Agric. Sci., Ain Shams Univ., Cairo, 13(3), 707-715, 2005

(Jayasuriya, 1993 and Pham el al 2001), notably in developing countries, such as Algeria.

Among herbivores, camels are considered particularly as able to convert any type of biomass into energy due to their presumably specific microflora activity and their ability to adapt to different and severe environmental conditions (Engelhardt et al 1987). The available data deals essentially with the physiological properties of the camels, such as their resistance to heat and thirst. Its digestive aspects and physiology pattern have been illustrated only during the last decade (Kayouli et al 1991; Kayouli et al 1995; Jouany et al 1995 and Dulphy et al 1995).

The use of non conventional substrate as feeding substance has not yet been subjected to significant studies. For this reason, the present research aimed to study the fermentation capacity of dromedary ruminal microflora towards some agro-industrial by-products retained for their availability in our country. The effect of the nature feeding resource on its in vitro gas production kinetics, was also examined.

\section{MATERIAL AND METHODS}

\section{Substrates}

Substrates used in this experiment were dates, oranges, olive residues and hay (standard substrate). These substrates had a known chemical composition (Table 1). Samples were taken from an industrial firm of transformation and conservation of dates (relegated dates). Orange residues were obtained from an industrial firm for jam and juice production (pulps and seeds). Olive waste was taken from traditional olive oil refinery (crushed olive).

Dates and oranges residues were dried at $45^{\circ} \mathrm{C}$ (in order to ovoid the Maillard reaction) and olive residues and hay at $105^{\circ} \mathrm{C}$ until constant weight. Samples were ground to pass a 1-mm sieve.

\section{In vitro gas production}

The substrates were incubated with rumen fluid in $100 \mathrm{ml}$ calibrated glass syringes following the technique of Menke et al (1979) and Menke \& Steingass (1988). The syringes were incubated at $39^{\circ} \mathrm{C}$ in an electrically heated, isothermal oven equipped with a rotor, which rolled continuously at nine rotations/min for 72 hours.

Rumen fluid was collected for each trial from three healthy dromedaries immediately after slaughter and stored in Thermos containers, at $39^{\circ} \mathrm{C}$ under saturated $\mathrm{CO}_{2}$. After straining with four layers of gauze, the rumen fluid was

1- Laboratoire de Génie Microbiologique et Applications, Département des Sciences de la Nature et de la Vie, Faculté des Sciences, Université des Frères Mentouri, Route de Ain-El-Bey BP 325, 25017 Constantine (Algerie).

2- Institut Technique des Elevages/Ain Mlila, 04000 Oum EL Bouaghi (Algerie).

a. Correspondant: Pr. Bousseboua Hacène (Tél./Fax: 0021331641435. E-mail: $\underline{\text { hblgma@yahoo.fr }}$

(Received April 6, 2005)

(Accepted June 25, 2005) 
mixed with the medium mixture solution of Menke and Steingass (1988) in a 1:2 ratio (v/v) and saturated with $\mathrm{CO}_{2}$.

For each substrate and each series of incubation, about $200 \mathrm{mg}$ of dried samples plus $30 \mathrm{ml}$ of rumen fluid and buffer (medium mixture solution) were incubated in triplicate. Under the same conditions, controls; hay (as standard substrate) plus blank syringe (without substrate) were also incubated in triplicate. Gas production was recorded at 2, 4, 6, 10, 24, 48 and 72 hours.

The quantitative analysis of gas production was obtained by direct reading of the level of piston displacement in the syringe and then the qualitative one is carried out using the procedure of Jouany (1982).

Net gas volume at each incubation period was calculated by subtracting the mean gas volume of the blank from the volume of gas in syringes with samples. The volume of gas was not corrected according to a standard substrate.

Data for gas production (mean of three observations) were fitted to the exponential model proposed by Orskov and McDonald (1979) and adapted for gas production by Blümmel and Orskov (1993): $p=a+b\left(1-e^{-c t}\right)$, where $p$ represents the net gas production at time $\mathrm{t},(\mathrm{a}+\mathrm{b})$ potential gas production and $\mathrm{c}$ the rate of gas production. Software developed by Chen (1997) was used to calculate the data.

\section{Statistical analysis}

The data were analyzed by one factor variance analysis (effect of substrate) using STAT-ITCF program.

\section{RESULTS AND DISCUSSION}

The kinetics of gas production is showed in Fig.1a. It follows an ascending pattern for the different substrates. The fermentation is relatively intensive during the first 24 hours of incubation, after which it reaches a stationary phase. However with certain substrates, it already started to decline. The kinetic of gas production appears to be determined by two distinct phases; the first one corresponds to the degradation of the soluble fraction of the tested substrate and the second to the insoluble but potentially fermentable fraction. The examination of the specific fermentation curves shows that the by-products of dates and oranges were more fermented than hay and olive residues $(\mathrm{P}<0.05)$ and their degradation occurs mainly during the first ten hours. Whereas, in the case of hay and olive residues, the fermentation is tributary of a latency phase.

The difference in the kinetics aspects of gas production between the dates and oranges residues from one side and those of hay is certainly a function of their chemical composition (Table 1), which indicates that the dates and oranges residues are rich in soluble sugars. In addition, their cell walls are less lignified compared to hay which is rich in cellulose (Gihad et al 1989).

Table 1. Chemical composition of the tested dates, oranges and olive residues, in relation to hay as a control samples.

Tested Substrates $\quad$ Abrev. DM $\quad$ Values are $\%$ of dry matter

Arab Univ. J. Agric. Sci., 13(3), 2005 
Arab Univ. J. Agric. Sci., Ain Shams Univ., Cairo, 13(3), 707-715, 2005

\begin{tabular}{|c|c|c|c|c|c|c|c|}
\hline & & & \\
\hline & & & $\begin{array}{c}\text { Total } \\
\text { sugars }\end{array}$ & $\begin{array}{l}\text { Crude } \\
\text { protein }\end{array}$ & $\begin{array}{l}\text { Crude } \\
\text { fat }\end{array}$ & $\begin{array}{c}\text { Crude } \\
\text { fiber }\end{array}$ & $\begin{array}{c}\text { Total } \\
\text { ash }\end{array}$ \\
\hline Dates residues & $\mathrm{RD}$ & 91.1 & 82.6 & 2.85 & 0.54 & 2.93 & 2.4 \\
\hline Oranges residues & $\mathrm{RC}$ & 19.5 & 25.9 & 5.57 & 2.34 & 11.9 & 4.37 \\
\hline Olives residues & $\mathrm{RO}$ & 68.2 & 5.14 & 0.97 & 15.6 & 40.9 & 1.61 \\
\hline Hay & $\mathrm{H}$ & 90.1 & 2.9 & 6.1 & 1.3 & 51.3 & 5.6 \\
\hline \multicolumn{2}{|c|}{ Standard Error of means (SEM) } & 0.53 & 1.76 & 0.41 & 0.62 & 2.7 & 0.25 \\
\hline
\end{tabular}

$\mathrm{DM}=$ Dry matter

1- Laboratoire de Génie Microbiologique et Applications, Département des Sciences de la Nature et de la Vie, Faculté des Sciences, Université des Frères Mentouri, Route de Ain-El-Bey BP 325, 25017 Constantine (Algerie).

2- Institut Technique des Elevages/Ain Mlila, 04000 Oum EL Bouaghi (Algerie).

a. Correspondant: Pr. Bousseboua Hacène (Tél./Fax: 0021331641435.

E-mail: hblgma@yahoo.fr

(Received April 6, 2005)

(Accepted June 25, 2005) 
Gas kinetics in rumen fluid of dromedary
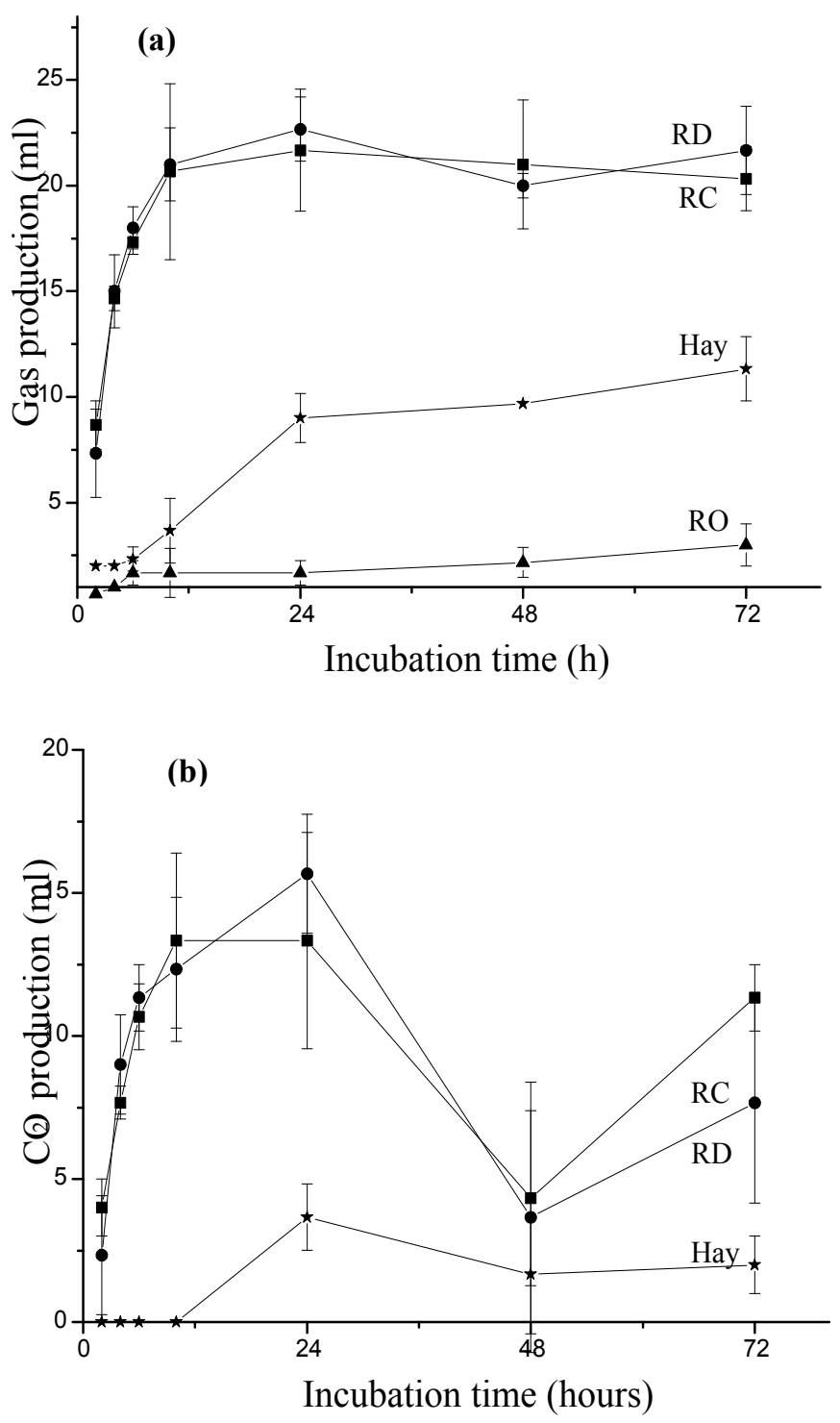

Fig. 1. Effect of substrate nature on in vitro gas production kinetics.

(a) total volume, (b) volume of $\mathrm{CO}_{2}$ and (c) volume of $\mathrm{CH}_{4}$.

Rd: Dates residues, Rc: Orange residues, Ro: Olives residues 
Arab Univ. J. Agric. Sci., Ain Shams Univ., Cairo, 13(3), 707-715, 2005

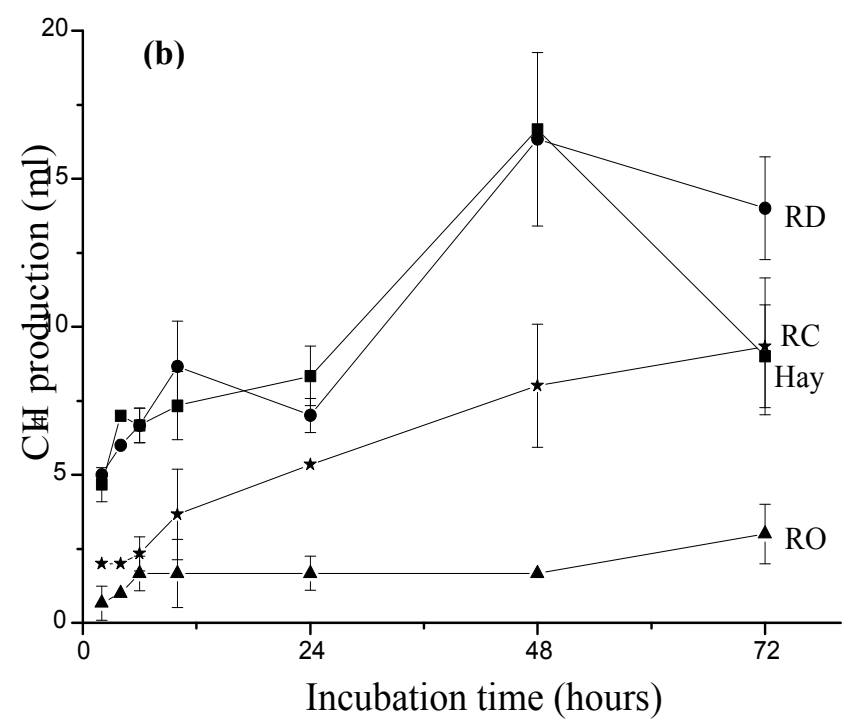

Fig. (1): Cont.

The weak gas production, observed with olive residues, has also been mentioned by Theriez and Boule (1970). This result could be explained by the fact that olive residues contain phenolic and tannic substances which are characterised by the unsolubilization of protein and the inhibition of microbial activity. Their effect is important mainly during the first hours of incubation (Leinmüller et al
1991). The pressed olive residues traditionally contain a part of pulp and around $40 \%$ of nucleus which are rich in fatty acids. These fatty acids are converted into calcic salts in the presence of calcium and magnesium (compounds of the buffer solution). These ions are primordial for the adhesion of cellulolytic bacteria to the cellulose (Tamminga and Doreau, 1991). This situation could also

1- Laboratoire de Génie Microbiologique et Applications, Département des Sciences de la Nature et de la Vie, Faculté des Sciences, Université des Frères Mentouri, Route de Ain-El-Bey BP 325, 25017 Constantine (Algerie).

2- Institut Technique des Elevages/Ain Mlila, 04000 Oum EL Bouaghi (Algerie).

a. Correspondant: Pr. Bousseboua Hacène (Tél./Fax: 0021331641435.

E-mail: $\underline{\text { hblgma@yahoo.fr }}$

(Received April 6, 2005)

(Accepted June 25, 2005) 
Arab Univ. J. Agric. Sci., Ain Shams Univ., Cairo, 13(3), 707-715, 2005

be an explanation for the weak gas production.

The qualitative analysis of gas produced is illustrated by Figs. $1 \mathrm{~b}$ and $1 \mathrm{c}$. It reveals that the degradation patterns of dates and oranges residues are similar. In the first hours of incubation, the dominant gas released is $\mathrm{CO}_{2}$; beyond 24 hours of incubation, an inverse tendency takes place and $\mathrm{CH}_{4}$ becomes dominant. Concerning hay, both $\mathrm{CO}_{2}$ and $\mathrm{CH}_{4}$ are produced with a little disequilibrium in favour of $\mathrm{CH}_{4}$. However, the degradation of olive residues produces exclusively $\mathrm{CH}_{4}$. In the same way, it was found that the $\mathrm{CO}_{2}$ and $\mathrm{CH}_{4}$ production, observed in vitro for dates and oranges residues, evolves the other way around during fermentation. This result agree with those mentioned in vivo by Vermorel (1995).

The production of gas during fermentation is correlated with both the quantitative and qualitative production of volatile fatty acids (Orskov and Ryle, 1990). Numerous authors suggest that the degradation substrate rich in starch and soluble sugars favours the production of propionic and butyric acids (Orskov et al 1988). These products are related to $\mathrm{CO}_{2}$ production. Otherwise, the fermentation of fibrous substrates produces acetic acid itself, being associated with an important production of $\mathrm{H}_{2}$ which induces an increased production of gas in the form of $\mathrm{CH}_{4}$. This leads us to deduce that the degradation of dates and oranges residues, which are rich in soluble sugars, might favour the production of propionic and butyric acids but that of fibrous substrates (olive residues and hay) favour the production of acetic acid.

Table (2) shows that the values of soluble fraction (a), obtained from the exponential model after 72 hours of incubation, are positive as well as negative. The negative values have also been reported by other authors working under the same conditions or in Sacco (Orskov \& Ryle, 1990 and Blümmel \& Orskov, 1993). They are associated to more less long latency phase and they could be explained by the necessary time to ruminal microflora to degrade soluble fraction and then to adhere to cellulosic fraction of the substrate. Furthermore, the dates and oranges residues are characterised by a fast fermentation than hay and olives residues $(\mathrm{P}<0.05)$.

Table 2. Cumulative in vitro gas production $(\mathrm{ml})$ after 72 hours of incubation and substrate fermentation characteristics defined by the exponential equation

$$
p=a+b\left(1-e^{-c^{*} t}\right)
$$

1- Laboratoire de Génie Microbiologique et Applications, Département des Sciences de la Nature et de la Vie, Faculté des Sciences, Université des Frères Mentouri, Route de Ain-El-Bey BP 325, 25017 Constantine (Algerie).

2- Institut Technique des Elevages/Ain Mlila, 04000 Oum EL Bouaghi (Algerie).

a. Correspondant: Pr. Bousseboua Hacène (Tél./Fax: 0021331641435.

E-mail: hblgma@yahoo.fr

(Received April 6, 2005)

(Accepted June 25, 2005) 
Arab Univ. J. Agric. Sci., Ain Shams Univ., Cairo, 13(3), 707-715, 2005

\begin{tabular}{|cccccccc|} 
RC & 21.0 & $20.3^{\mathrm{a}}$ & $25.2^{\mathrm{a}}$ & $21.0^{\mathrm{a}}$ & $35.26^{\mathrm{a}}$ & 0.50 & 1.98 \\
RO & 2.1 & $3^{\mathrm{c}}$ & $2.5^{\mathrm{c}}$ & $2.20^{\mathrm{c}}$ & $9.23^{\mathrm{b}}$ & 0.35 & 0.46 \\
$\mathrm{H}$ & 9.67 & $11.3^{\mathrm{b}}$ & $12.4^{\mathrm{b}}$ & $12.5^{\mathrm{b}}$ & $5.90^{\mathrm{b}}$ & 0.16 & 1.02 \\
$\mathrm{SEM}$ & 1.08 & 1.53 & 3.45 & 1.5 & 3.91 & & \\
\hline
\end{tabular}

abc Means in the same column without letter in common differ significantly $(\mathrm{P}<0.05)$.

* For abreviants, sea Table, 1.

1- Laboratoire de Génie Microbiologique et Applications, Département des Sciences de la Nature et de la Vie, Faculté des Sciences, Université des Frères Mentouri, Route de Ain-El-Bey BP 325, 25017 Constantine (Algerie).

2- Institut Technique des Elevages/Ain Mlila, 04000 Oum EL Bouaghi (Algerie).

a. Correspondant: Pr. Bousseboua Hacène (Tél./Fax: 0021331641435.

E-mail: hblgma@yahoo.fr

(Received April 6, 2005)

(Accepted June 25, 2005) 
Arab Univ. J. Agric. Sci., Ain Shams Univ., Cairo, 13(3), 707-715, 2005

\section{CONCLUSION}

The results of the present study complement the important studies made on dromedary by physiologists in the last decade, and indicate the greater hydrolytic activity of the dromedary ruminal microflora against substrates rich both in soluble fraction and cell wall compounds.

The results show also that the substrate nature is a determining factor for in vitro gas production. In fact, the substrate rich in cellular content is characterised by a fast fermentation that moves towards $\mathrm{CO}_{2}$ production, and it is marked by a long latency phase. On contrary, the fibrous substrate degradation is also tributary of less long latency period and generates $\mathrm{CH}_{4}$.

Concerning the nutritive value of the studied substrates, the obtained results indicate that dates and oranges residues might represent an acceptable source of energy for dromedary. Whereas, the olive residues, in spite of being rich in organic matter, cannot be used in animal feeding. However, their use as a constituent of feeding ration can be considered, perhaps after a treatment aimed to eliminate the inhibitory factor of the ruminal microflora and increase the solubility of its protein contents.

\section{REFERENCES}

Blümmel, M. and E.R. Orskov (1993). Comparison of in vitro gas production and nylon bag degradability of roughages in predicting feed intake in cattle. Anim. Feed Sci. Technol., 40: 109-119.

Chen, X.B. (1997). Neway Exel: $\boldsymbol{A}$ Utility for Processing Data of Feed Degradability and in vitro Gas Production (Version 5.0). Rowett Research Institute, Aberdeen, UK.

Dulphy, J.P.; W. Martin-Rosset and J.P. Jouany (1995). Ingestion et digestion comparée des fourrages chez les différents espèces d'herbivores. INRA Production Animale, 8: 293-307. Engelhardt W.V. ; M. Lechner-Doll; R. Heller, H.J. Schwartz and W.C. Ernest (1987). Utilization of agricultural waste products in animal nutrition. Anim. Res. Dev., 26: 56-69.

Gihad E.A.; T.T. El-gallad; A.E. Sooud; H.M. Abou El-Nasr and M.F.A. Farid (1989). Feed and water intake, digestibility and nitrogen utilisation by camels compared to sheep and goats fed low protein desert by-products. Options Méditerranéennes, 2: 75-80. Jayasuriya M.M. (1993). Use of crop residues and agro-industrial by-products in ruminant production systems in developing countries. Brit. Soc. Anim. Prod., 16: 47-55.

Jouany J.P. (1982). Volatile fatty acids and alcohols determination in digestive content, silage juice, bacterial culture and

1- Laboratoire de Génie Microbiologique et Applications, Département des Sciences de la Nature et de la Vie, Faculté des Sciences, Université des Frères Mentouri, Route de Ain-El-Bey BP 325, 25017 Constantine (Algerie).

2- Institut Technique des Elevages/Ain Mlila, 04000 Oum EL Bouaghi (Algerie).

a. Correspondant: Pr. Bousseboua Hacène (Tél./Fax: 0021331641435. E-mail: $\underline{\text { hblgma@yahoo.fr }}$

(Received April 6, 2005)

(Accepted June 25, 2005) 
10

Arhab; Dehimi; Dib and Bousseboua

anaerobic fermentation content. Science des Aliments, 8: 293-307.

Kayouli C.; J.P. Jouany and J. Ben Amor (1991). Comparison of microbial activity in the forestomachs of the dromedary and the sheep measured in vitro and in sacco on Mediterranean roughages. Anim. Feed Sci. Technol., 33: 237-245.

Kayouli C.; J.P. Jouany; C. Dardillat and J.L. Tisserand (1995). Particularités physiologiques du dromadaire: conséquences sur son alimentation. In: Options Méditerraneennes, Ciheam, Paris Série B : Etudes et recherches, 13: 143-155.

Leinmüller E.; H. Steingass and K.H. Menke (1991). Tannins in ruminant feedstuffs. Anim. Res. Dev., 33: 9-53.

Menke K.H. and H. Steingass (1988). Estimation of the energetic feed value obtained from chemical analysis and in vitro gas production using rumen fluid. Anim. Res. Dev., 28 :7-55.

Menke K.H.; L. Raab; A. Salewski; H. Steingass; D. Friz and W. Schneider (1979). The estimation of the digestibility and metabolizable energy content of ruminant feeding stuffs from the gas production when they are incubated with rumen liquor in vitro. J. Agric. Sci. Camb., 92 : 217-222.

Orskov E.R. and I. MCDonald (1979). The estimation of protein degradability in the rumen from incubation measurements weighed according to rate of passage. $\boldsymbol{J}$. Agric. Sci. Camb., 92: 499-503.

Orskov E.R.; G.W. Reid and M. Kay (1988). Prediction of intake by cattle from degradation characteristics of roughages. Anim. Prod., 46: 2934.

Orskov E.R. and M. Ryle (1990). Energy Nutrition in Ruminants. pp. 1-10.
Elsevier Applied Science (ed.), Amstrdam.

Pham Kim Coung; Vu Chi Cuong; Le Viet Ly and Jan Berg (2001). Straw yield, in sacco degradability and in vitro gas production of several rice varieties in the Red River Delta in Vietnam. Proceeding-Workshop on Improved Utilisation of by-Products for Animal Feeding in Vietnam.-NUFU-Project3/2001.

Tamminga S. and M. Doreau (1991). Lipids and rumen digestion. In: Rumen microbial metabolism and ruminant digestion, Jouany J.P. (ed)., INRA (Paris), 151-163.

Theriez M. and G. Boule (1970). Valeur alimentaire du tourteau d'olive. Ann. Zootech., 19(2): 143-157.

Vermorel M. (1995). Production gazeuses et thermiques résultant des fermentations digestives. In: Nutrition des Ruminants Domestiques : Ingestion et Digestion. pp. 92-102. Jarrige R.; Y. Ruckebusch; C. Demarquilly; M.H. Farce et Journet M. (eds). INRA, Paris, France. 
Arab Univ. J. Agric. Sci., Ain Shams Univ., Cairo, 13(3), 707-715, 2005

1- Laboratoire de Génie Microbiologique et Applications, Département des Sciences de la Nature et de la Vie, Faculté des Sciences, Université des Frères Mentouri, Route de Ain-El-Bey BP 325, 25017 Constantine (Algerie).

2- Institut Technique des Elevages/Ain Mlila, 04000 Oum EL Bouaghi (Algerie).

a. Correspondant: Pr. Bousseboua Hacène (Tél./Fax: 0021331641435.

E-mail: hblgma@yahoo.fr

(Received April 6, 2005)

(Accepted June 25, 2005) 


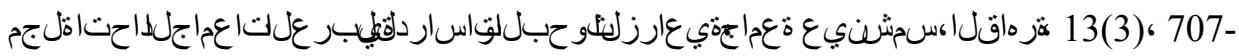
715، 2005

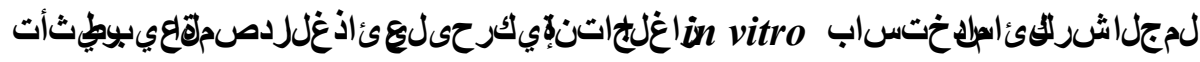

]46[

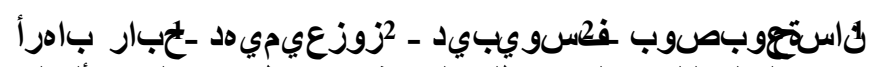

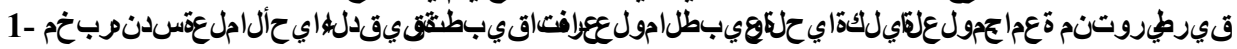

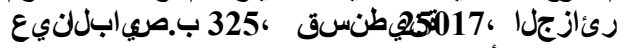

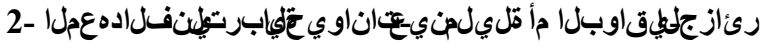

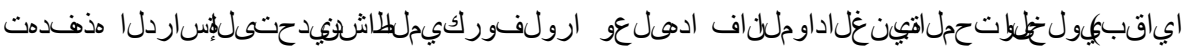

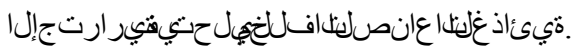

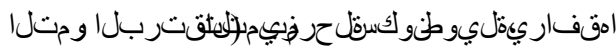

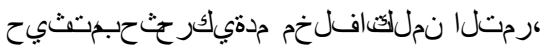

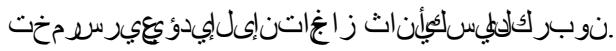

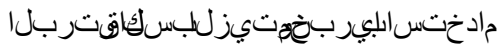

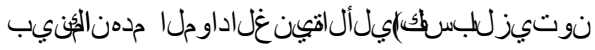

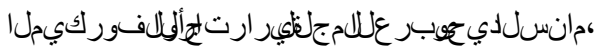

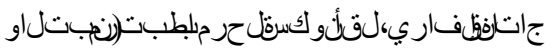

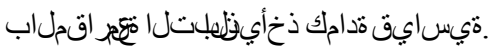

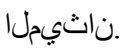

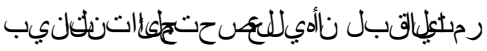

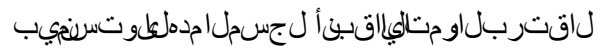

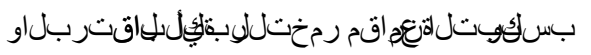

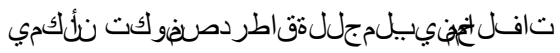

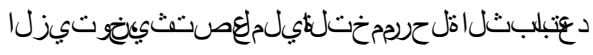

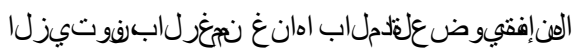

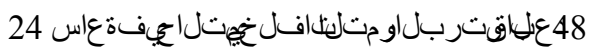

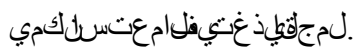

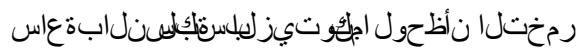

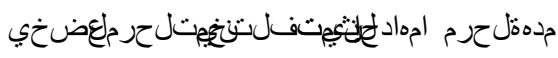

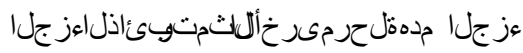

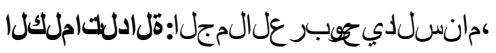

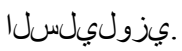

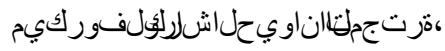

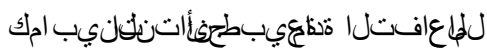

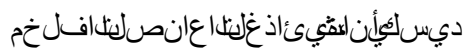

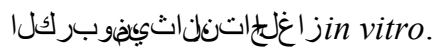

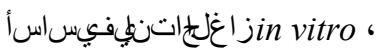
مللبلعنبيمأ دمجم ن:جيكحت 